\title{
Auditors' Perceptions of Corporate Governance in Hong Kong
}

\author{
Philip Law*, Desmond Yuen \\ Avenida da Universidade, Taipa, University of Macau, Macau, China \\ Email: ^PLaw@umac.mo
}

How to cite this paper: Law, P. and Yuen, D. (2018) Auditors' Perceptions of Corporate Governance in Hong Kong. Open Journal of Accounting, 7, 82-92.

https://doi.org/10.4236/ojacct.2018.71006

Received: December 18, 2017

Accepted: January 15, 2018

Published: January 18, 2018

Copyright (C) 2018 by authors and Scientific Research Publishing Inc. This work is licensed under the Creative Commons Attribution International License (CC BY 4.0).

http://creativecommons.org/licenses/by/4.0/

\begin{abstract}
Corporate governance system plays an important role in the contemporary accounting and management literature. The purpose of this study is to examine the auditors' perceptions on corporate governance in the Hong Kong market. 92 experienced professionals of Big 4 audit firm auditors are interviewed to summarize the ideas of how to maintain an efficient corporate governance system. Results of the study show that effective corporate governance should avoid family directors to dominate the board. Second, effective audit committee plays a crucial role in order to maintain sound corporate governance. The study would be advantageous for listed companies in HK to adopt a better corporate governance structure in the firm.
\end{abstract}

\section{Keywords}

Corporate Governance, Auditors, Audit Committee

\section{Introduction}

Corporate governance can be defined as the process affected by a set of legislative, regulatory, legal, market mechanisms, listing standards, best practices and efforts of all corporate governance participants, which create a system of checks and balances with the goal of creating and enduring the interests of the stakeholders. The role of corporate governance is changing during the past several decades. From the early developments, corporate governance is designed to ensure that management acts in the sustainable well-being of the company and its shareholders. Recent developments since 2000s, corporate governance enlarges its functions and is now more focus on the effectiveness of protecting shareholders and its stakeholders such as creditors, employees and customers from managerial misconduct and corporate malfeasance (Rezaee, 2009) [1]. To prevent the financial scandals in listed companies in U.S, corporate governance 
reforms and SOX and related SEC implementation rules arose in the late 1900s. These reforms require strong personal ethics and responsibilities, professional accountability and more transparent disclosure to all of the related parties. Corporate Governance is now from the role of reducing agency cost to creating long-term value to shareholders and increasing the value of all of the stakeholders. Different countries have different corporate governance structure, and different structures show the nature of culture, social, legal and economic system. In Rezaee's (2008) [2] opinion, the corporate governance structure should be based on three interrelated components; they are corporate governance principles, functions and mechanisms. As the corporate law, standards, management style and culture are different in different countries; this is the gap that this study seeks to address. This Hong Kong study aims to obtain the Big 4 auditors' perceptions of a corporate governance system. As auditors' roles for carrying out their external monitoring function are important, this study tries to provide a contribution in the corporate governance literature. This research will start to describe the corporate governance functions, the literature review, and interviews will be conducted on Big 4 auditors in Hong Kong.

\subsection{Corporate Governance Functions}

The primary goal of any companies is to create long term and substantial value, and building a world class corporate governance system provides a blueprint that every stakeholders work effectively. To achieve the goal of enduring value, corporate governance has a role of forming, governing, monitoring and maintaining with a group and related companies. And it can also be an important benchmark that companies can make a progress by learning other companies' successes and faults (Thomas and Susan, 2010) [3].

The functions of corporate governance are essential in the corporate governance structure. Rezaee (2008) [2] introduces that a well-balanced company can run the seven functions effectively and these interrelated functions can implement each other and produce reliable corporate governance. The seven functions are oversight, managerial, compliance, internal audit, advisory, external audit, and monitoring. The figure of seven functions is shown by Figure 1.

\subsubsection{Oversight Function}

The oversight function is the function of board of directors. Board of directors has the duty to oversee the managerial function in order to provide the best value to the company and its shareholders. The oversight function is crucial because board of directors represents the best interests of shareholders and is designed to monitor the managers. It is an important function to try to resolve the agency problem between the principals (shareholders) and agents (managers). (Fama and Jensen, 1983) [4].

In Hong Kong, the board of directors consists of executive directors and impendent non executive directors. The effectiveness of the function mainly depends on the directors' independence, and the board of directors should give out 


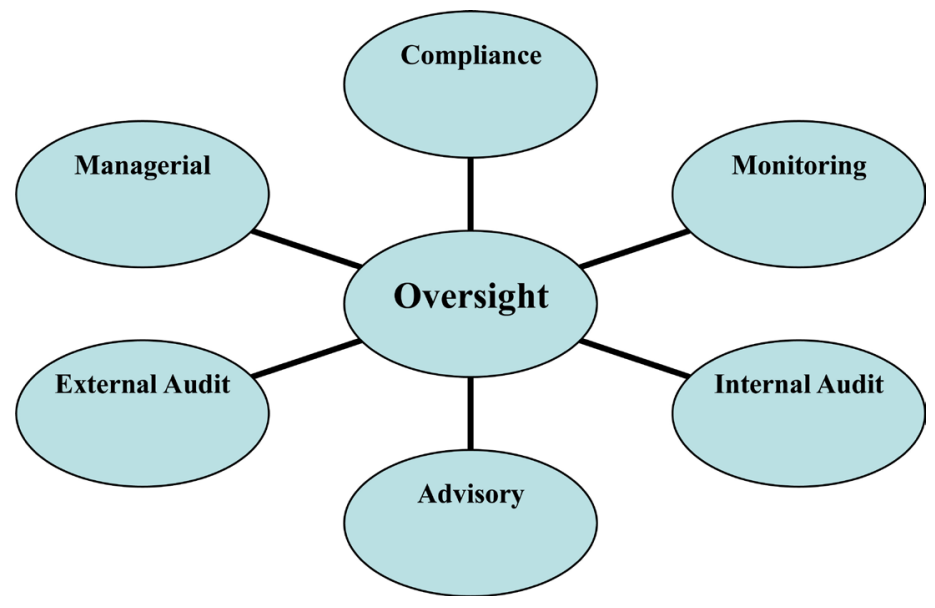

Figure 1. Corporate Governance Functions.

the strategic suggestions to management, however, the advice and oversee should be limited to macro managing.

\subsubsection{Managerial Functions}

This function of corporate governance is granted to management in order to run the business and manage the resources. The managers have responsibilities of disclosing the financial and non-financial information of companies. When managers perceive the importance of corporate governance, it will have a positive impact on their performance by enhancing the credibility of the company or organization. Management can also build up a better social accountability by improving the trust, the level of dialogue and communications with the company, and it will bring out a better long-term outcome (Teerooven and Aamina, 2008) [5]. The effectiveness of this function mainly depends on the ethics of managers and the managers' bonus linked with company performance.

\subsubsection{Compliance Function}

The compliance function consists of a set of laws, rules, standards and regulations which are developed by governance or professional organizations. They set up a corporate governance framework for public companies to follow and achieve their goals. However, there are different standards between countries. Robert (2002) [6] stated that one of the pioneers of corporate governance, the U.S., has the main corporate governance in 2002 by having the Sarbanes-Oxley Act (SOX) of 2002 and implementing rules and regulations. They are all adopted in the New York Stock Exchange, the American stock Exchange and Nasdaq. The compliance function in the U.S with the SOX and related actions give them a new era of compliance and it means that listed companies should conduct a broader review of their corporate governance, risk management and compliance system. Companies should not only assure the compliance with the letter of the law but also keep the accountability and effective corporate governance system. However, there are no laws and regulations similar to SOX in China and Hong Kong stock market. 


\subsubsection{Internal Audit Function}

This function mainly involves the internal audit and advisory department. Internal auditors play an important role in providing assurance and consulting services, forming companies' corporation governance, internal control and risk management structure, financial reporting and governance processes. In the past years, internal audit department is mainly focus on assurance and consulting services in compliance with the related regulations of the country. However, in the coming years, they should expand their responsibilities in reducing agency costs and complexity of the company, enhancing risk management and assisting in strategic and governance processes. Furthermore, internal auditors should have a closer working relationship with audit committee in order to improve the corporate governance system (Rezaee, 2010) [7].

About the relationship between audit committees and internal auditors, Marlene (2009) [8] states that it is imperative that committees and internal auditors can both work as a team to make the internal audit function effective. Audit committees have an important role in accessing the performance of the internal audit function by appointing the head of internal audit department and therefore internal auditors have confidence to conduct internal audit work.

\subsubsection{Legal and Financial Advisory Function}

In a company, it is common to have legal department or to hire consulting companies to provide the legal advice and help the company, directors, managers and employees to comply with the law and related corporate governance standards; The financial advisers provide the planning and advises of the tax and finance to the company. Sometimes it is hard to clarify whether the advisory company or legal department is effective to the company or not. Andre and Barry (2002) [9] suggest that advisory services have a critical role to play at the beginning of the company or on the process of reforming but their importance will gradually become inconsequential because they are generally replaced by a board of directors for practical and legal reasons.

\subsubsection{External Audit Function}

This function is exercised by external auditors in giving an audit opinion that financial statements are fairly and truly represented and the company's position and the operations comply with generally accepted accounting principles (GAAP). External auditors add value to the company's corporate governance through their audit work of internal control and financial operations. The risk and control development in corporate governance is changing the role of the external auditor. Claus and Peter (2007) [10] suggested that as the corporate governance has enhanced the role of internal auditor in advantage of the role of the external auditor, external auditors should rethink about their roles in corporate governance and add the value to their audit work and the nature of an audit. They must be perceived as experts in risk management and internal control area in order to add value to the role of corporate governance. And they should also 
improve and communication process of audit reporting and the transparency when conducting audit work.

\subsubsection{Monitoring Function}

The last function is performed by shareholders, especially for institutional shareholders to elect and change the member of board of directors. The shareholders elect the board of directors, and directors appoint managers (CEO, $\mathrm{CFO})$ to manage the company. Shareholders show the indirect function to corporate governance and monitor the whole company by using their proposals and nominations to the board of directors. Even though in U.S, corporate governance does not work fully in the right way because board of directors fail to make the effective system they should and furthermore investors can not easily work as an active owners. It is suggested that the outside owners should make more active way to communicate with board of directors and involve more in the company. And the independent directors and investors should act as monitors of corporate governance not only when the issues happen, but also paying efforts continually (Lipton and Lorsch, 1992) [11].

\section{Motivation of the Research}

Much research has been conducted concerning direct impact on corporate governance in U.S or in Europe. However, there are not much researches of corporate governance in HK. As the corporate law, standards, management style and culture are different; this is the gap that this study seeks to address. In the wake of previous corporate governance failure in $\mathrm{HK}$, most, a vast number of managers, shareholders, internal and external auditors, and public stakeholders are finding it necessary to redevelop their internal control and corporate governance system in response to the developing and optimizing market of intense competition in China.

\section{Literature Review}

\subsection{Corporate Governance in China}

Apart from the industrialized countries such as U.S., UK and Canada that have had a long period to develop and improve their corporate governance structure, the corporate governance structure of Chinese listed companies is modeled after other countries. China is attempting to change from planned economy to market oriented economy in just a short time. Unlike one-tier board system in UK and US, the China boards require two-tier board structure which is similar to Japan's and Germany's corporate structure (Charkham, 1992) [12]. One-tier board system means that there is only one board system including executive directors and non-executive directors. Independent non-executive directors play an important role of monitoring internal control. Since 1990s, China has made a great progress in some aspects of corporate governance. In the developing of corporate governance in China, American style corporate governance mechanism 
plays an important role as it has been the models of the world and China also learned from American style of corporate governance. But the recent financial scandals such as Enron and Lehman Brothers, and the cultural differences reflect that China should learn from mistakes, keep their own way to improve corporate governance and not to just follow the western model of corporate governance (Yuan, 2009) [13].

Conducting a corporate governance study in China is critical since the Chinese economy is developing rapidly and the status of China becomes more and more important in international society since China has been one of the members of the WTO. However, most of the studies related to corporate governance were concentrated on US and other Western countries. Not much relevant study is performed in HK. So this study aims to improve corporate governance structure and performance, and ultimately to benefit Chinese economy development.

\subsection{Board of Directors}

According to Fama and Jensen (1983) [4], the board of directors has the responsibilities in monitoring the company's activities for shareholders and finally contributes to the maximization of the corporate value. In China, the board of directors also plays an important in monitoring and ensuring the corporate governance structure. And similarly, they are also authorized to represent the interest of shareholders to make decisions on electing senior management, the company's strategic decisions and they also contributes internal mechanisms in ensuring senior management to perform in the way that is linked with the value of shareholders (Hongxia and Michelle, 2010) [14]. As the board of directors is one of the key parties in the corporate governance, it is important to adjust the structure of the board of directors in order to enhance the company transparency and comply with the corporate governance system. Hsiang-Tsai and Li-Jen (2010) [15] find that enhancing the compensation of directors and continuous education are both effective ways to encourage the company board of directors to act better in the interests of shareholders and to achieve stronger and transparent governance.

\subsection{Senior Management}

The company's managers are under the oversight strategies of the board of director and they are all responsible for the interests of shareholders. Their responsibilities include but not limited to the company's operations, the performance assessment, decision making on the company's activities and fair presentation of the financial reports. Independence is regarded as an important attribute of managers in the corporate governance. When senior managers own higher proportion of the company or the CEO and the Chairman is the same person, it is less likely to change their board structure and improve the corporate governance (Lasfer, 2006) [16]. As hundreds of companies have been destroyed by the management's fraud, it is suggested that a strong internal and external 
governance mechanism may force managers to act in the best interests of shareholders and not in their personal desires (Sian et al., 2010) [17]. Tone at the top in the company is also a key factor of establishing effective ethical culture and it may also affect the corporate governance system. Tone at the top refers to the ethical environment that is created by the top management. If the tone set by senior managers is ethical and integrated, employees of the company will intend to perform and act well as their managers. However, if the top management upholds unethical and just focus on the bottom line of the standards, employees will appear more chances to commit fraud because they know that codes of conducts are not the focus or the first priority of the top management (Dana et al., 2008) [18].

\subsection{External Auditors}

External Auditors also can play an important role in the effective corporate governance as a value-added component. In the U.S., the independent directors are required to meet external auditors separately and then external auditors may get some useful information from independent directors and provide suggestions to board of directors. However, communications between external auditors and independent directors in China are less than in the U.S. It may restrict the external auditors' functions to contribute an effective corporate governance system (Steven and Sudha, 2009) [19]. And Mahmud et al. (2010) [20] state that legal environment and Auditor's choice can also affect corporate governance. They found that when the companies choose the high-quality auditors under a strong legal environment, it will benefit to the effective corporate governance as auditors and companies are both subject to more serious legal punishments. And one of the potential issues involving external auditors is the appropriateness of providing non-audit consulting services to the company because it may seriously affect the independence of external auditors (Joseph, 2009) [21].

\subsection{Audit Committee and Internal Auditors}

According to SOX, Audit committee and internal auditors often work together to ensure the internal control effectiveness and therefore contribute to the corporate governance system. Internal auditors are the key factor in the governance, risk management, internal control and compliance and furthermore, they should anytime aware of the argument that may break the compliance rules. (Stephen and Jon, 2010) [22]. On the other hand, audit committee should play a role of monitor to internal auditors and they should have responsibilities of hiring, compensating, firing internal auditors, and overseeing the works of internal auditors. In some of the countries, like the U.S. or even India, audit committees act various functions in the financial reporting, financial analysis, and audit planning, internal control and so on. And they are one of the most key factors in corporate governance as they also act as a bridge of communications between board of directors and external auditors (Rajeev et al., 2010) [23]. In summary, 
all the corporate governance participants would create a system of checks and balances with the goal of creating and enduring the interests of the stakeholders. The innovative of this research is that we capture the views of the external auditors with whom they are performing an external monitoring role in the corporate governance.

\section{Methodology}

92 interviews are conducted on Big 4 auditors in Hong Kong. After collecting data by interviews, we need to analyze the information of the interviewees. In this study, content analysis will be used to summarize and evaluate the content of the interviewees. Content analysis is a method for compressing many words into fewer content categories based on explicit rules of coding (Krippendorff, 1980) [24]. It is a useful technique for allowing us to describe what the group of interviewees is focus on. All of the information is finally collected and analyzed to some useful points of view that help us to know how we can do better in corporate governance and what we should pay attention on. The questions we ask in the interview would be in the area of how to better maintain effective corporate governance in a company.

\section{Results}

92 auditors are interviewed and the results are as follow (Table 1(a) and Table $1(\mathrm{~b}))$.

Table 1. (a) Suggestions of forming board of directors?; (b) What should be improved in board of directors in Chinese companies?

(a)

\begin{tabular}{ccc}
\hline Suggestions & Frequency & Percent \\
\hline Avoiding family members to dominate the board & 26 & 28.2 \\
Have good faith and codes of ethics & 22 & 23.9 \\
Having various kinds of professionals in the board & 20 & 21.7 \\
Avoiding the conflicts of interest in the board & 11 & 11.9 \\
Acting for the benefits of shareholders and other stakeholders & 8 & 8.6 \\
Having long term view to lead the company success & 5 & 5.4 \\
\hline
\end{tabular}

(b)

\begin{tabular}{ccc}
\hline Suggestions & Frequency & Percent \\
\hline Enhancing the audit committee monitoring functions & 30 & 32.6 \\
Separation their roles between ownership and control & 21 & 22.8 \\
Pay more attention to internal control & 14 & 15.2 \\
Pay more attention to risk management & 12 & 13.04 \\
Think more about the long term value but not short term & 8 & 8.6 \\
Protecting interests of management and other stakeholders & 7 & 7.6
\end{tabular}


From the results analyzed about, the view of enhancing the audit committee monitoring functions is shared by most of the professionals, one manager stated:

"I would pay more attention on monitoring top management. Audit committee role is very crucial. However, they focus less on the codes of ethics of top management and internal control effectiveness because such performance is not easily seen and evaluated, many frauds happen due to less monitoring. And the worse case is: the chairman and the CEO is the same person. So the audit committee monitoring role plays a very important part."

\section{Conclusion and Implications}

The main implication of this study is to provide some recommendations to the owners of Chinese listed companies and the regulation makers. First of all, this study provides the recommendations to key parties in order to establish and maintain an effective corporate governance system. The recommendations are based on the interviews of auditors, but it could also be extended to other Chinese listed companies. Furthermore, this study also finds that regulations and effective internal control are also crucial in corporate governance. In this area, China and Chinese listed companies have a long way to go. But it is sure that more optimized standards and regulations are required and the transparency of companies should be enhanced to public in long term. The contribution of this study is that we capture the perceptions of the big 4 auditors in Hong Kong. As Hong Kong is one of the key financial center in the market, their views on the corporate governance would be a useful guidance to all the participants in the market.

\section{Limitations}

There are some limitations of this study. First, this study mainly focuses on auditors views. Other users or stakeholder' view are ignored. Although the response rate of this study is satisfactory, we cannot capture the perceptions of the non-auditors. In the future, we can cover the perceptions of a wider group of participants such as financial specialists, internal auditors in industry, the public and other stakeholders. In order to examine the similarities or differences perceptions among different groups of people, a longitudinal study would be valuable to conduct in the future.

\section{References}

[1] Rezaee, Z. (2009) Corporate Governance Post-Sarbanes-Oxley: Regulations, Requirements, and Integrated Processes. The CPA Journal, 79, 15

[2] Rezaee, Z. (2008) Corporate Governance and Ethics. Willey, NJ.

[3] Sabatino, T.J. and Wol, S.E. (2010) Subsidiary Governance: What It Is, Why It Matters and How to Build a Good System. The Corporate Governance Advisor, 18, 5-10.

[4] Fama, E.F. and Jensen, M.C. (1983) Separation of Ownership and Control. Journal of Law and Economics, 26, 301-326. https://doi.org/10.1086/467037 
[5] Soobaroyen, T. and Sheik-Ellahi, A. (2008) A Case Study on the Influence of Corporate Governance beyond the Boardroom: Perceptions from Business Unit Managers. Corporate Governance, 8, 179-190.

https://doi.org/10.1108/14720700810863805

[6] Bostrom, R. (2002) Corporate Governance, Risk Management and Compliance: Best Practices after Sarbanes-Oxley. International Financial Law Review, 21, 165-176.

[7] Rezaee, Z. (2010) The Importance of Internal Audit Opinions. The Internal Auditor. Altamonte Springs, 67, 47-50.

[8] Davies, M. (2009) Effective Working Relationships between Audit Committees and Internal Audit-The Cornerstone of Corporate Governance in Local Authorities, a Welsh Perspective. Journal of Management \& Governance, 13, 41-74. https://doi.org/10.1007/s10997-008-9070-9

[9] Morkel, A. and Posner, B. (2002) Investigating the Effectiveness of Corporate Advisory Boards. Corporate Governance, 2, 4-13. https://doi.org/10.1108/14720700210440035

[10] Holm, C. and Laursen, P.B. (2007) Risk and Control Developments in Corporate Governance: Changing the Role of the External Auditor? Corporate Governance: An International Review, 15, 322-333. https://doi.org/10.1111/j.1467-8683.2007.00563.x

[11] Lipton, M. and Lorsch, J.W. (1992) A Modest Proposal for Improved Corporate Governance. The Business Lawyer, 48, 59-78.

[12] Charkham, J.P. (1992) Corporate Governance: Lessons from Abroad. European Business Journal, 4, 8-17.

[13] Yuan, D.J. (2009) Inefficient American Corporate Governance under the Financial Crisis and China's Reflections. International Journal of Law and Management, 51, 139-152.

[14] Liu, H.X. and Fong, M.W.L. (2010) Board Characteristics of Medium and Large Chinese Companies. Corporate Governance, 10, 163-175.

https://doi.org/10.1108/14720701011035684

[15] Chiang, H.-T. and He, L.-J. (2010) Board Supervision Capability and Information Transparency. Corporate Governance: An International Review, 18, 18-31. https://doi.org/10.1111/j.1467-8683.2009.00779.x

[16] Lasfer, A. (2006) The Interrelationship Between Managerial Ownership and Board Structure. Journal of Business Finance \& Accounting, 33, 1006-1033. https://doi.org/10.1111/j.1468-5957.2006.00600.x

[17] Owen, S., Shi, L. and Yawson, A. (2010) Divestitures, Wealth Effects and Corporate Governance. Accounting and Finance, 50, 389-415. https://doi.org/10.1111/j.1467-629X.2009.00332.x

[18] Hermanson, D.R., Ivancevich, D.M. and Ivancevich, S.H. (2008) Tone at Top: Insights from Section 404. Strategic Finance, 90, 39-47.

[19] Mintz, S. and Krishnan, S. (2009) A Comparison of Corporate Governance in China and India with the U.S. The Business Review, 13, 60-67.

[20] Hossain, M., Lim, C.Y. and Tan, P.M.S. (2010) Corporate Governance, Legal Environment, and Auditor Choice in Emerging Markets. Review of Pacific Basin Financial Markets and Policies, 13, 91-126. https://doi.org/10.1142/S0219091510001883

[21] Carcello, J.V. (2009) Governance and the Common Good. Journal of Business Ethics, 89, 11-19. https://doi.org/10.1007/s10551-008-9904-Z 
[22] Davis, S. and Lukomnik, J. (2010) Enabling Good Governance. The Internal Auditor. Altamonte Springs, 67, 28.

[23] Puri, R., Trehan, R. and Kakkar, H. (2010) Corporate Governance through Audit Committee: A Study of the Indian Corporate Sector. IUP Journal of Corporate Governance, 9, 47-57.

[24] Krippendorff, K. (1980) Content Analysis: An Introduction to Its Methodology. Sage, Newbury Park, CA. 